\title{
The Entrenchment of the European Convention on Human Rights in the Italian Legal System - Following the Jurisprudence of the Italian Constitutional Court
}

\author{
Vittorio Manes ${ }^{\star}$
}

\begin{abstract}
I. The Status Assigned to the ECHR (and to Strasbourg Case-law) by Recent Italian Constitutional Jurisprudence - I.1. The Decisions no. 348 and no. 349 of 2007 and the ECHR provisions as "interposed standards" of a constitutionality review in light of Art. 117, par. 1, of the Italian Constitution - I.2. The corroboration of such an asset after the entry into force of the Lisbon Treaty: Decision no. 80 of 2011 - I.3. The impact of the Decisions issued by the Strasbourg Court on the national legal system: Judgment no. 113 of 2011 and the "new" cause for the reopening of a proceeding further to a condemnation judgment ruled by the European Court - II. The Alternatives Cast for Judges in Light of the Contrast between National and Conventional Provisions: an Interpretation Consistent with Convention Rights or Raising a Constitutional Legitimacy Question- II.1. The interpretation consistent with Convention rights as a privileged solution for Ordinary Judges - II.2. The constitutional legitimacy question raised by the alleged violation of Art. 117, paagraph 1, of the Italian Constitution - II.3. The analogy between the case analyzed by the Strasbourg ruling and the case concerning the question of constitutional legitimacy -III. The Limitations to the Integration of the ECHR within the Italian Legal Order: the Compliance with Constitutional Principles - IV. Conclusions.
\end{abstract}

\section{The status assigned to the ECHR (and to Strasbourg case-law) by recent Italian constitutional jurisprudence}

The integration process of the European Convention on Human Rights within the Italian legal system has been slow and laborious and - for quite long - has given rise to divergent and often conflicting jurisprudential paths, which mirrored the different and various resolutions evoked by academics from time to time.

However, such process has undergone a significant boost and improvement over the last five years; this finds its roots in some innovative decisions through which the Italian Constitutional Court has securely "entrenched" the ECHR "as interpreted by the European Court of Human Rights", within the Italian constitutional frame.

Following the Constitutional jurisprudence, the prominent phases of such an evolution may be articulated into three fundamental stages: first of all, the ECHR has been awarded the rank of "sub-constitutional" source of law, thus deeming conventional provisions and the rulings of the Strasbourg Court to be "interposed standards of constitutionality review", through Art. 117, paragraph 1, of the Constitution (Decisions no. 348 and no. 349 of 2007); secondly, the Court also

${ }^{\star}$ University of Salento, Italy 
confirmed this asset after the Lisbon Treaty entered in force, thus re-asserting the dissimilarity between the conventional system and EU law (Decision no. 80 of 2011); finally, the Court has introduced a specific ground for the revision of a condemnation judgment under Art. 630 of the Italian criminal procedure code, thus ruling on the effects of final condemnation judgments of the ECHR (Decision no. 113 of 2011$)^{1}$.

\section{The Decisions no. 348 and no. 349 of 2007 and the ECHR provisions as "interposed standards" of constitutionality review in light of Art. 117, par. 1, of the Italian Constitution}

The analysis obviously cannot cover all the jurisprudential paths which have followed over the years; nevertheless, it must be pointed out that for a long period of time the ECHR has been assigned quite an unclear setting by differing academic perspectives and consequent judicial opinions, thus making it difficult to find a spot of legitimacy either under Art. 10 of the Constitution ${ }^{2}$ (being a customary source and not consuetudinary) or under Art. 11 of the Constitution ${ }^{3}$ (as it does not introduce any "limitation on sovereignty"): the outcome thereof was its overration, at times (therefore finding direct application), while on other occasions, it was confined to a lower rank, or even deemed inadequate to compel the domestic legal system to its covenants and obligations. ${ }^{4}$

Such an ambiguous and uncertain setting, along with its fluctuating jurisprudential orientations, has been finally cleared by two basic rulings of the Constitutional Court - Decisions no. 348 and no. 349 of 2007, also known as the "twin decisions". 5 These have awarded the ECHR a sharper rank among the legal system

\footnotetext{
${ }^{1}$ For the latter Italian Constitutional Court jurisprudence on the ECHR, see further E.Lamarque, Gli effetti delle sentenze della Corte europea secondo la Corte costituzionale italiana, in: M. Fragola (ed.), La cooperazione tra Corti in Europa nella tutela dei diritti dell'uomo, 2012, p. 77 et seq.; $R$. Conti, La scala reale della Corte costituzionale sul ruolo della CEDU nell'ordinamento interno, Corriere giuridico, 2011, p. 1243 et seq.

${ }^{2}$ Art. 10, paragraph 1, of the Constitution states that "The Italian legal system conforms to the generally recognized principles of International law". As the Court has clarified and specified in numerous judgments, the words "generally recognized principles of international law" only refer to consuetudinary law and determine the automatic adaptation of the Italian legal system to the same. Customary dispositions, although they have a general range of application, are not encompassed within the governing sphere of Art. 10; and the ECHR pertains to the latter category, with the consequent "impossibility of adopting its rules as standards of constitutionality review (Decision no. 188 of 1980), or as interposed dispositions according to Art. 10 of the Constitution" (Order no. 143 of 1993, Decisions no. 153 of 1987, no. 168 of 1994, no. 288 of 1997, no. 32 of 1999, Order no. 464 of 2005).

${ }^{3}$ It is well known that Art. 11 of the Constitution - in the part in which it agrees to the limitations of sovereignty that may be necessary to promote and encourage international organizations furthering the end of ensuring peace and justice among nations - has been recognized as the constitutional ground on the basis of which full binding force is granted to Community rules, which find direct application (Decisions no. 183 of 1973, no. 170 of 1984 and no. 284 of 2007), albeit excluding that this may be taken into account with reference to the ECHR dispositions ("because it is not possible to identify in the specific treaty provisions under examination any limitation on national sovereignty": Decision no. 188 of 1980).

${ }^{4}$ And this, in particular, because its dispositions have never been assigned - by the Court's case-law - a constitutional rank, as it is not possible to award them a rank which is different from that of the act - ordinary law (i.e. Law no. 848 of August 4, 1955) - which has authorized their ratification and has enacted them within our legal system: among the others, see Decisions no. 388 of 1999, no. 315 of 1990, no. 188 of 1980.

${ }^{5}$ For an English version of the aforementioned Decisions no. 348 and no. 349 of 2007, see http://www. cortecostituzionale.it/ActionPagina_328.do; for an analysis of these judgments, see e. g. O. Pollicino, Constitutional Court
} 
hierarchy, as it has been acknowledged as a "sub-constitutional" source, more specifically as an "interposed standard of constitutionality review", through Art. 117, paragraph 1, of the Constitution (a disposition which compels legislative powers to comply to "[...] the constraints deriving from EU legislation and International obligations").

Basically, the "intermediate status" granted to the ECHR, now seen as an "interposed source of law" anchored to Art. 117 of the Constitution, has enabled the Constitutional Court to reaffirm the necessary subordination of the conventional provisions to constitutional principles (and not only with the "counter-limits" which encompass EU law); i. e. the rules of the Convention as interpreted by the Court of Strasbourg ${ }^{6}$ do not acquire the same force of constitutional dispositions (and they do not go exempt from constitutionality review). On the other hand, the Court has nonetheless affirmed the pre-eminence of the conventional provisions with respect to ordinary law, so that the contrast between the latter and a disposition of the ECHR shall give forth to a contrast with a constitutional principle (i. e. Art. 117, par. 1, of the Constitution), which may be ruled by the Court.

As said, through the aforementioned Decisions no. 348 and no. 349 of 2007, the integration between our domestic legal order and the ECHR has surely accomplished an important step forwards, through which, at the level of the theory of legal sources, a difference, and under certain aspects even a progression has been marked with respect to other legal systems such as the German one.

Actually, in Germany the Convention is awarded the same force of ordinary laws without prejudice to the fact that the so called Völkerrechtsfreundlichkeitsprinzip, which refers both to ordinary laws and the Grundgesetz, also imposes an "interpretation consistent with Convention rights" (konventionskonformeAuslegung), given in any case

at the crossroads between constitutional parochialism and co-operative constitutionalism. Judgments No. 348 and 349 of 22 and 24 October 2007, European Constitutional Law Review, 2008, p. 363 et seq.; S. Mirate, A new status for the European Convention on Human Rights in Italy. The Italian Constitutional Court and the new "Conventional review" on national laws, European Public Law, 2009, p. 89 et seq.; F. Biondi Dal Monte-F. Fontanelli, Decisions No. 348 and $349 / 2007$ of the Italian Constitutional Court: The Efficacy of the European Convention in the Italian Legal System - Part I/II, German Law Journal, 2008, p. 889 et seq.

${ }^{6}$ See, critically, P. Ferrua, L'interpretazione della Convenzione europea dei diritti dell'uomo e il preteso monopolio della Corte di Strasburgo/ The judicial interpretation of the European Convention of Human Rights and Fundamental Freedoms and the alleged monopoly of the European Court of Human Rights, Processo penale e Giustizia, 2011, p. 116 et seq.

${ }^{7}$ From a comparative constitutional perspective, see particularly D. Spielmann, Jurisprudence of the European Court of Human Rights and the Constitutional systems of Europe, in: M. Rosenfeld-A. Sajó (eds.), The Oxford Handbook of Comparative Constitutional Law, 2012, 12311252; G. Martinico, Is the European Convention Going to Be 'Supreme'? A Comparative-Constitutional Overview of ECHR and EU Law before National Courts, European Journal International Law, 2012, p. 401 et seq.; Ch. Tomuschat, The Effects of the Judgments of the European Court of Human Rights according to the German Constitutional Court, in M. Fragola (fn. 1), p. 99 et seq.; P. Pérez Tremps, La experiencia española de aplicación de las "cartas" europeas de derechos humanos por el Tribunal constitucional, in M. Fragola (fn. 1), p. 115 et seq.; O. Pollicino, L'impatto della Convenzione europea e della giurisprudenza di Strasburgo sulla giurisprudenza costituzionale dei Paesi dell'Europa centro-orientale membri dell'Unione europea, in M. Fragola (fn. 1), p. 133 et seq.; E. Bjorge, National supreme courts and the development of ECHR rights, International Journal Constitutional Law, 2011, p. 5 et seq.; G. Martinico-O. Pollicino, The National Judicial Treatment of the ECHR and EU Laws. A Comparative Constitutional Perspective, 2010; H. Keller-A. Stone Sweet, A Europe of Rights: The Impact of the ECHR on National Legal Systems, 2008. 
the limit of the compliance to the principles of the Basic Law (following the s.c. reservation of sovereignty imposed by the $G G){ }^{8}$

In any event, the Italian system has not yet achieved the level of integration sometimes guaranteed in other legal systems, ${ }^{9}$ where the courts are less reluctant to unapply national legislation in order to ensure the primacy and direct effect of many Convention provisions. ${ }^{10}$

However, by choosing to convey conventional provisions under Art. 117, par. 1, of the Constitution, the Court has nonetheless reasserted the persisting distance between the ECHR and EU law (which finds access through the principle stated in Art. 11 of the Constitution): the first is not comparable to the latter, and therefore cannot determine certain effects, such as the instant non application by ordinary Judges of those internal provisions conflicting with Community rules (s.c. Neutralisierungswirkung/Anwendungsvorrang).

To this end it has been expressly stated that while "By adhering to the Community treaties, Italy became part of a broader supra-national "legal order", ceding part of its sovereignty, including legislative powers, in the fields covered by those treaties, subject only to the limit of the mandatory nature of the principles and fundamental rights guaranteed in the Constitution[...]", the same cannot be stated with respect to the ECHR, as it "does not create a supra-national legal order and does not therefore produce provisions directly applicable in the signatory States" (Decision no. 348 of 2007).

\footnotetext{
${ }^{8}$ More specifically, in German legal system the Convention has been assigned the status of federal law, thus overiding alla laws enacted by the Länder; it has therefore a lower rank than the Grundgesetz, but has nevertheless binding effect, as applicable statute law, for all organs of the executive and for all courts. Actually, the obligation of interpreting dispositions in compliance with the ECHR, after all, is pointed out also by the German Constitutional Court, although even in its recent jurisprudence the Convention is not awarded with a "sub-constitutional" source of law (see C. Grabenwarter, Wirkungen eines Urteils des Europäischen Gerichtshofs für Menschenrechte - am Beispiel des Falls M. gegen Deutschland, JZ, 2011, p. 861 et seq.; Ch. Michaelsen, 'From Strasbourg, with Love'Preventive Detention before the German Federal Constitutional Court and the European Court of Human Rights, Human Rigths Law Review, 2012, p. 148 et seq.)For more details, D. Spielmann(Fn. 7), p. 1236 et seq.; on thistopicseefurtherH. Satzger, DerEinflussder EMRK aufdasdeutscheStraf- und Strafprozessrecht - Grundlagen und wichtigeEinzelprobleme, Jura, 2009, 759 et seq.; Id., Internationales und europäischesStrafrecht, 4. Auflage, 2010, 191etseq.; seealsoK. Ambos, InternationalesStrafrecht, 2. Auflage, 2008, p. 356etseq..

${ }^{9}$ E.g., on the status of the Convention and the contrôle de conventionnalitè in the French legal system, where the Cour de Cassation and the Conseil d'Etat have accepted the direct effect of many Convention provisions, and admit the possibility of unapplying national legislation conflicting with them, see further D. Spielmann (Fn. 7), p. 1237 et seq.; the author underlines that in Belgium it has also been recognized that ordinary courts (including the highest administrative court, the Conseil d'Etat) are competent to review the compatibility of any statute with the provisions of an international treaty such as the ECHR, rejecting the application of the conflicting provisions of domestic law, and notes that - according to recent case law - the Convention even prevails over the Belgian Constitution (p. 1241 et seq.).

${ }^{10}$ However, among Italian law scholars there are those who outline that - at the level of the theory of legal sources - the ECHR should be assigned a different rank, not a "sub-constitutional" one but a "para-constitutional" one, and this "in light of the subject-matter treated and, above all, of the way it is treated, which extraordinarily covers the entire number of the fundamental principles of the legal order", above all articles 2 and 3 of the Constitution $(A$. Ruggeri, Rapport tra CEDU e diritto interno: Bundesverfassungsgericht e Corte costituzionale allo specchio, www. giurcost.org, p. 3), thus hinting a distinction which would therefore grant to such source an upgraduation with respect to the other International conventions.
} 


\section{The corroboration of such an asset after the entry into force of the Lisbon Treaty: Decision no. 80 of 2011}

From this last perspective, the framework of the so-called "twin decisions" and the (radical) difference in terms of imperativeness (and of effects) between EU law and the ECHR have both been substantially reinforced by later jurisprudence (Decisions no. 311 and no. 317 of $2009^{11}$ ), and have found further acknowledgement within Decision no. 80 of $2011^{12}$, through which the Constitutional Court has reaffirmed the impossibility for the dispositions of the ECHR of finding direct application even after the entry into force of the amendments enacted through the Lisbon Treaty. According to certain approaches promoted by legal scholars, such modifications seemed to have determined an "incorporation" of the ECHR within the European Union legal order, and consequently the self executing effect and the "Anwendungsvorrang" of its provisions within the single National legal systems, comparable to that of EU rules.

In actual fact, the rephrasing of Art. 6 of the TEU seemed to offer a lever to the thesis of the so-called "Communitarization" of the ECHR, that is, of its "incorporation" within the European Union legal order, with the consequent recognition of its effects in the National legal system: such provision, in fact, besides establishing that "The Union recognizes the rights, freedoms and principles set out in the Charter of Fundamental Rights of the European Union [...] which shall have the same legal value as the Treaties" (Art. 6.1) - also foresees that "the Union shall accede to the European Convention for the Protection of Human Rights and Fundamental Freedoms" (specifying however that "such accession shall not affect the Union's competences as defined in the Treaties": Art. 6.2), and above all that "fundamental rights, as guaranteed by the European Convention [...] and as they result from the constitutional traditions common to the Member States, shall constitute general principles of the Union's law".

The issue - in light of the inclusion of the Nice Charter in the Treaties (also known as the so-called "consecration" of the Nice Charter) - seemed to be further complicated by the equivalence clause under Art. 52 of the Charter, which states that insofar as the Charter contains rights which correspond to rights guaranteed by the ECHR, "the meaning and scope of those rights shall be the same as those laid down by the said Convention" (Art. 52.3, which also adds that "this provision shall not prevent Union law providing more extensive protection") $)^{13}$.

\footnotetext{
${ }^{11}$ For an English version of the aforementioned Italian Constitutional Court's Judgments, see http://www.cortecostituzionale.it/ActionPagina_325.do.

${ }^{12}$ An English translation of Corte costituzionale's Decision no. 80 of 2011 is available at http://www.cortecostituzionale.it/ActionPagina_1134.do; on this decision, see T. Cerruti, Cedu, UE e parametri di costituzionalità: è cambiato qualcosa dopo l'entrata in vigore del Trattato di Lisbona?, Giurisprudenza italiana, 2012, p. 777 et seq.; S. Fùrfaro, Pubblicità dell'udienza in cassazione e regole europee: incongruenze sistematiche e ripensamenti inopportuni (a proposito di Corte cost., sent. n. 80 del 2011), Archivio Penale, 2011, p. 983 et seq.

${ }^{13}$ See, e. g., G. Strozzi, Il sistema integrato di tutela dei diritti fondamentali dopo Lisbona: attualità e prospettive/ The integrated system for protection of fundamental rights after Lisbon: the current situation and new prospects, Diritto dell'Unione europea, 2011, p. 837 et seq.; S. Douglas-Scott, The European Union and Human Rights after the Treaty of Lisbon, Human Rights Law Review, 2011, p. 645 et seq.
} 
In spite of the fact that this thesis had also found certain support in some decisions issued by ordinary judges (administrative judges) ${ }^{14}$, the Constitutional Court - as said, through its Decision no. 80 of 2011 - has found the claimed "Communitarization" of the ECHR to be ungrounded: on one hand, it has pointed out that the accession of the EU to the ECHR is still in progress, therefore denying it of any effects; on the other hand - also in light of a previous argumentation - the Court has once more affirmed that the fundamental rights, as general principles of Union law "are significant exclusively in relation to the matters to which Community law (now Union law) is applicable, and not also to matters regulated by national legislation alone".

Even with reference to the "incorporation" of the Nice Charter within the Treaties (the so-called "consecration" of the Nice Charter), which according to such a framework would also have indirectly concerned the ECHR, the Court has had a chance to clarify that the protection of fundamental rights - promoted by the Charter with full juridical effects - cannot in any case modify nor extend the competences of the Union, other than those established within the Treaties: competences or powers that are therefore laid down in EU law, and which do not extend to those subject-matters exceeding from its sphere. As a result, "a prerequisite for the applicability of the Nice Charter is therefore that the case placed before the court for examination is governed by European law - insofar as it concerns acts of the Union and national acts and conduct implementing Union law, or justifications adopted by a Member State for a national measure which would otherwise be incompatible with Union law - and not simply national legislation with no link with Union law": for that reason there was no chance of incidence in this proceeding, which related to a preventive measure and the request for the application of the principle of publicity of the hearing, denied by National law and - according to the applicants instead - imposed by Art. 6 of the ECHR.

Conclusively, the current orientation of the Italian Constitutional Court has settled on a position according to which the National provisions contrasting and incompatible with the ECHR cannot be set aside (by ordinary judges through the forms of "diffuse constitutional control"), as they may only be subject to constitutionality review (i.e. by the Constitutional Court, through the usual "concentrated" constitutional review) ${ }^{15}$.

\footnotetext{
${ }^{14}$ Consiglio di Stato, Section IV, Judgment of 2 March 2010, No. 1220; Tar Lazio, Section II bis, Judgment of 18 May 2010, No. 11984, both available at www.giustizia-amministrativa.it. In general, for an overview on the Italian administrative jurisprudence after the "twin-decisions", see S. Mirate, The role of the ECHR in the Italian administrative case law. An analysis after the two judgments of the Constitutional Court No. 348 and No. 349 of 2007 , Italian Journal of Public Law, 2009, p. 260 et seq.

${ }^{15}$ However, it needs to be pointed out that alongside the constitutional jurisprudence outlined above there are also scholars who suggest a further distinction, affirming that a direct application of the Conventional provision could nonetheless be possible "when the latter covers a gap in the domestic legislation, without determining the misapplication of any incompatible National provision", thus being this last procedure possible even with respect to rules - such as the ECHR and its protocols - "which are anyhow incorporated in National legislation in light of the clause "full and complete effect" contained in the acts which authorize their enactment": F. Viganò, Fonti europee e ordinamento italiano, in: F. Viganò-O. Mazza (eds.), Europa e diritto penale, special issue of Diritto penale e processo, 2011, p. 18).
} 
3. The impact of the Decisions issued by the Strasbourg Court on the national legal system: Judgment no. 113 of 2011 and the "new" cause for the reopening of a proceeding further to a condemnation judgment ruled by the European Court

Ultimately, the path covered by the ECHR and leading to its integration into the National legal order has reached a further, important step through Decision no.113 of $2011^{16}$, through which the Constitutional Court has considered the specific issue of the effects of (condemnation) judgments ruled by the Strasbourg Court within our legal system ${ }^{17}$.

More specifically, the above cited Judgment has declared the partial illegitimacy of Art. 630 of the Italian criminal procedure code, related to the part in which it did not provide for a criminal proceeding to be reopened according to Art. 46 of the ECHR if the original judgment had been ruled unfair by a final judgment of the European Court, due to the violation of a right or of a guarantee granted by the Convention in the course of the proceeding (and therefore not only due to the violation of the fair process under Art. 6 of the ECHR $)^{18}$.

As a result, in the current panorama of the Italian legal order this opening to the Conventional system has entailed that even a final judgment in a criminal trial may now be destined to surrender before the impact with the "force tranquille" of human rights ${ }^{19}$.

\section{The alternatives cast for judges in light of the contrast between national and conventional provisions: An interpretation consistent with Convention rights or raising a constitutional legitimacy question}

In spite of this last aspect it must nonetheless be pointed out that the "new" hierarchy of sources of law as set out by the above outlined Court Decisions, while

\footnotetext{
${ }^{16}$ For an English version of Decision no. 113 of 2011, see http://www.cortecostituzionale.it/ActionPagina_1134.do; see, for comments on the Decision, G. Repetto, Corte costituzionale e CEDU al tempo dei conflitti sistemici, Giurisprudenza costituzionale, 2011, p. 1548 et seq.; G. Ubertis, La revisione successiva a condanne della Corte di Strasburgo, Giurisprudenza costituzionale, 2011, p. 1542 et seq.; S. Lonati, La Corte costituzionale individua lo strumento per adempiere all'obbligo di conformarsi alle condanne europee: l'inserimento delle sentenze della Corte europea tra i casi di revisione, Giurisprudenza costituzionale, 2011, p. 1555 et seq.; A. Logli, La riapertura del processo a seguito della sentenza CEDU. Questioni interpretative sul nuovo caso di "revisione europea", Cassazione penale, 2012, p. 393 et seq.; G. Canzio, Giudicato "europeo" e giudicato penale italiano: la svolta della Corte costituzionale, Associazione italiana dei costituzionalisti (web journal), 2011, p. 1.

${ }^{17}$ For an overview of the Italian situation previous to Decision no. 113 of 2011, see R. De Caria, The fork in the road after Strasbourg: effective remedy or moral victory? A provocative interpretation of the duty to 'Abide by the final judgment' of the European Court of Human Rights, from the Italian perspective, Comparative Law Review, 2010 , p. 1 et seq.

${ }^{18}$ See A. Ruggeri, "Itinerari” di una ricerca sul sistema delle fonti, 2012, p. 313 et seq.; M.R. Geraci, La revisione quale rimedio interno dopo le condanne della Corte di Strasburgo: un avanzamento di tutela e molte incognite/The "revisione" as a national instrument to comply with the Human Rights Court's decisions: more guarantees, many doubts, Processo penale e Giustizia, 2011, p. 93 et seq.

${ }^{19}$ For other examples, see C. Tracogna, The influence of the ECHR Jurisprudence on the National Criminal Procedure system. The Italian perspective: from divergence to realignment, Lex et scientia International Journal, 2010, p. 84 et seq.
} 
addressing the ECHR as an "interposed standard" of constitutionality review, has determined a precise "hierarchical binding force" both for judges and legislator: in the presence of a conflict between an ordinary law and a Conventional disposition "in line with the meaning attributed by the court specifically charged with its interpretation and application" (i.e. the wording used by the Constitutional Court), it will rest principally with the judge to try to adopt any adaptable and consistent interpretation; if, eventually, the hermeneutical interpretation were not possible, then the judge may/must raise an incidental constitutional legitimacy question in order to challenge the legitimacy of the domestic provision (thus in light of the contrast with Art. 117, par. 1, of the Constitution, and "mediately" with the relevant Conventional provision at cause, which shall convert to the so-called "interposed standard" of constitutionality review).

The duty of interpreting dispositions in compliance with the ECHR is therefore the primary measure in order to adapt the national legal order to the provisions of the Convention ${ }^{20}$, and its principal addressees are, above all, the courts of the Member States "which are the ordinary courts in relation to Convention law" (Decision no. 349 of 2007): it is in fact the domestic judge who shall engage and adopt all efforts to eliminate the asymmetry between the National law provision and the Conventional provision and therefore interpret the former in a manner compatible with the Convention "insofar as permitted by the text of the provisions under comparison and using all normal instruments of legal interpretation" (Decision no. 311 of 2009).

Nevertheless, should this attempt of granting an adaptive interpretation consistent with Convention rights not be possible (for example because the wording of the statute is clear and the consistent interpretation would distort the littera legis), then the judge - as he won't be able to proceed either with the direct application of the ECHR provision in place of the contrasting domestic one, nor, on the other hand, with the application of a domestic provision which he himself had deemed to be contrasting with the ECHR - must refer the issue to the Court, in order to require a "judicial surgical intervention" able to annul the existing conflict with the Conventional provision ${ }^{21}$.

\section{The interpretation consistent with Convention rights as a privileged solution for Ordinary judges}

To this end, it must be stressed that before raising a legitimacy question the judge shall have closely valued whether it could have been possible to resolve the contrast issue by way of interpretation, and this in light of the fact that - as constantly repeated by our Constitutional Court -“(...) laws are not to be declared constitu-

\footnotetext{
${ }^{20}$ Actually, such hermeneutical binding had also been acknowledged by earlier judgments, prior to the "twin decisions": e. g., Decision no. 505 of 1995; Decision no. 305 of 2001.

${ }^{21}$ Thus, raising the question with reference to the violation of Art. 117, paragraph 1, of the Constitution or even of Art. 10, paragraph 1, of the Constitution when the Conventional disposition recalls an International provision which in its own part refers to generally recognized principles of International law: see, to this end, Decision no. 311 of 2009 .
} 
tionally illegitimate because an unconstitutional interpretation may be given to them (...), but because it's impossible to grant them a constitutional one" (Decision no. 356 of 1996, widely confirmed in later judgments).

After all, should the judge not have explored the possibility of providing an interpretation consistent with Convention rights before prospecting a contrast in front of the Court, then the raised legitimacy question shall be destined to be ruled inadmissible (see, for example, Decision no. 239 of 2009, in a case of confiscation and non retroactivity principle). ${ }^{22}$

\section{The constitutional legitimacy question raised by the alleged violation of Art. 117, paragraph 1, of the Italian Constitution}

On the other hand, should an interpretation consistent with Convention rights not be possible - for example because it would distort the meaning of the provision, thus determining a conflict with the littera legis - then the Constitutional legitimacy question may be justly raised in order to challenge the contrast of a disposition with the Conventional provision (in light of Art. 117, par. 1, of the Constitution), and - if grounded - it may direct to a judgment of acceptance issued by the Court.

An example, to this extent, is offered by Decision no. 196 of $2010,{ }^{23}$ which has declared the discipline introduced with reference to issues regarding the confiscation of a vehicle in cases of drunk driving to be constitutionally illegitimate in the part in which it recalled the tempus regitactum rule, thus imposing the retrospective application of a confiscation measure which however - in light of the ECHR jurisprudence undisputedly presented "criminal" aspects, falling within the concept of "matiére pénale" and - consequently - within the protection area (Schutzbereich) granted by Articles 6 and 7 of the ECHR. ${ }^{24}$

More specifically, the case examined in Judgment no. 196 of 2010 concerned the discipline of the confiscation of a vehicle introduced for the most serious hypothesis of criminal offence committed by drunk driving, which was retrospectively applicable thanks to the explicit reference made to the discipline of security measures (Maßnahmen) by explicitly recalling Art. 240 of the Italian Criminal code. ${ }^{25}$

\footnotetext{
${ }^{22}$ For this Decision see http://www.cortecostituzionale.it/ActionPagina_325.do.

${ }^{23}$ On the decision, see V. Manes, La confisca "punitiva" tra Corte costituzionale e CEDU: sipario sulla "truffa delle etichette", Cassazione penale, 2011, p. 76 et seq.

${ }^{24}$ On the concept of "matière penale", which indicates the field of protection (Schutzbereich) of Art. 7 ECHR, see H.Satzger (Fn. 8), 217; V. Manes, in: S. Bartole-P. De Sena-V. Zagrebelsky (ed.), Commentario breve della Convenzione europea dei diritti dell'uomo, 2011, Art. 7, p. 259 et seq.

${ }^{25}$ Art. 186, paragraph 2, letter c) of the Legislative Decree no. 285 of 1992 (New road and traffic law rules), as amended by Art. 4 of the Law Decree no. 92 of 2008 (Urgent measures to ensure safety) and converted, with amendments, into Law no. 125 of 2008; such provision, in the new version of Art. 4, paragraph 1, letter $b$ ), foresees the "confiscation of the vehicle with which the criminal offence under Art. 240, paragraph two, of the criminal code, has been committed, unless such a vehicle belongs to a person unrelated to the criminal offence", in case of final condemnation both for drunk driving, when the driver is found to have reached an alcoholic level higher than 1.5 grams per litre of haematic substance [Art. 186, paragraph 2, letter c) of the New Highway Code], and for driving under the effect of drugs and therefore in a state of psycho-physical alteration.
} 
In its decision the Court has shared the evaluations of the referring Court, and underlined the punitive and repressive function (and not merely preventive) of the confiscation measure at cause (given anyhow that such a measure is applicable even when the vehicle has suffered an accident and is temporarily out of use, and that its exertion does not prevent the use of other means of transportation by the accused -therefore a risk for the repetition of crime remains - so that the measure itself would not be finalized to neutralize the situation of danger for which the prevention has been conceived).

On such basis, in light of the detected contrast with Article 117, par. 1, of the Constitution with regard to the profiles outlined above, and of the impossibility of solving the issue through consistent interpretation, the Court has declared the partial illegitimacy of the provision (limited "only to the words "in compliance with Art. 240, paragraph 2, of the criminal code", the sole from which the retrospective application of the measure at cause derives").

\section{The analogy between the case analyzed by the Strasbourg ruling and the case concerning the question of Constitutional legitimacy}

Furthermore, one of the most problematic aspects, to this end, concerns the reference to and the use of the European Court's precedents and the related acknowledgment of correspondence, in terms of "analogy", between the case examined in the "supranational" judgment and the case considered in the domestic one $^{26}$.

Such acknowledgment in terms of analogy represents a basic postulation in order to "import" a principle affirmed in Europe within a proceeding of Constitutional legitimacy control; as the Italian Constitutional Court has stated in its Decision no. 239 of 2009, for example, such principle must be cited in point by the referring judge. In the above-cited case, the Court ruled the question inadmissible, also on the basis of the consideration that "[...] in order to justify the extrapolation from the specific precedent of the Strasbourg Court of a principle of law which could constitute the basis for the question of constitutionality, the referring court should have established through argument in a plausible manner the analogy between that specific case and that, not necessarily identical, on which it had been called to pass judgment"27.

\footnotetext{
${ }^{26}$ See P. Fusaro, Il linguaggio non verbale della Corte Costituzionale: la 'politica giudiziaria' nei confronti della Convenzione europea dei diritti umani/The non-verbal language of the Italian Constitutional Court: the "judicial policy" concerning the Convention for the Protection of Human Rights and Fundamental Freedoms, Diritti umani e diritto internazionale, 2011, p. 507 et seq.

${ }^{27}$ Judgment no. 196 of 2010 has properly motivated, for example, the analogy among the cases at cause, through arguments which have convincingly deemed to retain applicable, in case of confiscation of a vehicle, the criteria through which the European Court describes the concept of "criminal law matter", thus calling to look "behind the appearances" so to extend to all "intrinsically punitive measures" the warranties granted under Art. 7 of the ECHR.
} 


\section{The limitations to the integration of the ECHR within the Italian legal order: The compliance with constitutional principles}

The primacy awarded to the Convention within the Italian legal order isn't of course unconditional and it incurs uncertain limits, as it must always obey to the "supremacy" of the Constitution ${ }^{28}$.

To this end, and yet again moving from Judgments no. 348 and 349 of 2007, the Court has stated that the "interposed" Conventional provisions which have come into view as integrating sources of the mentioned standard of constitutionality review (Art. 117, par. 1, of the Constitution), may find access within the Italian legal order only when they do not prove to be incompatible with other provisions of the Italian constitutional order.

In other words, the integration of the Convention within the Italian legal order is always subject to the compliance with the framework of the constitutional principles it needs to uphold: more specifically, with all principles, and not only with the fundamental principles and rights guaranteed by the Constitution, i. e. the "supreme principles" which according to constitutional jurisprudence set out the so-called counter-limits ("controlimiti”) towards EU law.

This is the reason for which the ECHR is defined, according to the phrasing of the Court, as a "sub-constitutional" source of law, taking this to mean that its provisions - which are destined to integrate Art. 117, par. 1, of the Constitution "supplement a constitutional principle, whilst always retaining a lower status" (Judgment no. 348 of 2007).

Furthermore, it has also been outlined that "the requirement that the provisions which supplement the constitutional principle themselves respect the Constitution is absolute and mandatory in order to avoid falling into the paradox of a legislative provision being declared unconstitutional on the basis of another interposed provision, which in turn breaches the Constitution", with the consequence that "in all questions flowing from claims of incompatibility between interposed rules and internal ordinary legislation, it is necessary to establish at the same time that both respect the Constitution, and more specifically that the interposed rule is compatible with the Constitution, as well as the constitutionality of the contested provision in the light of the interposed rules" (Judgment no. 348 of 2007).

From another perspective - while ascertaining the contrast between a domestic provision and a Conventional rule - the Court has also withheld the role of " $[. .$. verifying whether the provisions of the ECHR, as interpreted by the Strasbourg Court, guarantee a protection of fundamental rights that is at least equivalent to the level guaranteed by the Italian Constitution", given that "in this way, a correct balance is struck between the need to guarantee respect for international obligations required by the Constitution and to prevent this also resulting in a breach of the Constitution itself" (Judgment no. 349 of 2007).

${ }^{28}$ Cf. A. Ruggeri, (Sistema integrato di fonti e sistema integrato di interpretazioni, nella prospettiva di un'Europa unita), Integrated system of sources and integrated system of interpretation in the perspective of a united Europe, Diritto dell'Unione europea, 2010, p. 869 et seq. 
In other words, the Court shall prove that the conflict is determined by a lower level of safeguard and protection of the domestic provision if compared to the one guaranteed by the ECHR provision, taking into account that the reverse hypothesis is explicitly compatible under Art. 53 of the European Convention itself (Decision no. 311 of 2009).

As it has been more explicitly stated, "where a fundamental right is at issue, the need to comply with International law obligations can never constitute grounds for a reduction in protection compared to that available under internal law, whilst it can and must vice versa constitute an effective instrument for the broadening of that protection"; and the comparison with the Conventional system, although it needs to be balanced with other interests protected by the Constitution, "must be carried out seeking to obtain the greatest expansion of guarantees, including through the development of the potential inherent in the constitutional norms which concern the same rights", i. e. "the impact of individual ECHR rules on Italian law must result in an increase in protection for the entire system of fundamental rights" (Decision no. 317 of 2009).

In any case, should a conflict between a Conventional disposition and other provisions of our Constitution arise then the dynamic reference to International law will necessarily be excluded as well as its qualification to integrate the standard of Constitutionality review under Art. 117, par. 1, of the Constitution (and such hypothesis implies the illegitimacy of the enactment legislation, in consideration of the fact that it's not possible to affect the legitimacy of the standard of review itself: see Decision no. 348 and 349 of 2007; Decision no. 311 of 2009).

Along similar lines, the Constitutional Court has also progressively concentrated its attention towards other perspectives.

In fact, it has been stated that if the Constitutional Court, on the one hand, may not ignore the interpretative findings of the Strasbourg Court with regard to the ECHR provisions, on the other, it may nonetheless interpret it - of course while respecting the substantial European case-law on the matter - with "a margin of appraisal and evaluation which enables it to take into account the peculiarities of the legal system in which the Conventional provision is destined to find access[...]" (Decision no. 311 of 2009; similarly, Decision no. 236 and 303 of 2011).

On the basis of such "autonomy of evaluation" - for example - the Constitutional Court has denied the illegitimacy of the discipline referred to the derogation of the retrospective application of more favorable prescription terms (Verjährung) for certain criminal offences (Law no. 251 of 2005), in relation to which various legitimacy claims had been raised further to the known Judgment though which, for the first time, the European Court had asserted the retroactivity principle of the more lenient penalty (lexmitior) as an implicit corollary of Art. 7 of the ECHR (European Court of Human Rights, September 17, 2009, Scoppola v. Italy).

In particular, through its Decision no. 236 of 2011 the Italian Constitutional Court has stated, on one hand, that the above cited case of Scoppola v. Italia did not inhibit possible derogations (within the domestic order such derogations are tradi- 
tionally tied to the favorable retrospective application of penalties); on the other hand, it has outlined how - in light of Italian case-law - the principle of the more lenient penalty (lex mitior) needs to be viewed as only referable to the "provisions which define criminal offences and the penalties which punish them" (acting as a reminder of how the discipline of prescription terms receives an ambiguous allocation within the Strasbourg case-law, which deems it to be extraneous to "criminal matters").

Summarizing the above considerations, when the Constitutional Court has detected a contrast between a provision and a supranational rule which cannot be solved by way of interpretation, it has nonetheless awarded itself the power to verify, on the one hand "whether or not the ECHR provision, as interpreted by the Strasbourg Court, conflicts with other reference provisions of our Constitution" (Decision no. 311 of 2009), "should this be the case, the Court will be required to rule that the Convention provision is incapable of supplementing the principle of constitutional law concerned" (Decision no. 113 of 2011); on the other hand, the power to "assess how and to what extent the results of the interpretation of the European Court interact with the Italian constitutional order" (Decision no. 317 of 2009).

Such assessment is, after all, consistent with the prominent assignment given to the ECHR within the hierarchy of sources of law, and to the specific Constitutional standard through which it has found access within our legal system: it has been repeatedly underlined that "since an ECHR provision effectively supplements Article 117(1) of the Constitution, it receives from the latter its status within the system of sources, with all implications in terms of interpretation and balancing, which are the ordinary operations that this Court is required to carry out in proceedings falling within its jurisdiction" (Decision no. 317 of 2009; no. 236 and no. 303 of 2011).

\section{Conclusions}

In light of the above arguments, we may state that the progressive integration of the ECHR within the Italian legal order has seen a sensible increment over just a short time, thus determining a considerable improvement with concern to the protection and safeguard of the rights and fundamental freedoms taken into consideration time by time.

What is certain is that this process is still in progress, as there are still some "grey areas" which will need further clarification: among these - and this is just an example - is the progressive flowing from the European Court of Human Rights case-law of positive obligations having impact on national criminal law, ${ }^{29}$ which according

\footnotetext{
${ }^{29}$ See D. Xenos, The Positive Obligations of the State under the European Convention of Human Rights, 2011; F. Tulkens, The Paradoxical Relationship between Criminal Law and Human Rights, Journal of International Criminal Justice, 2011, p. 577 et seq.; L. Lazarus, Positive Obligations and Criminal Justice: Duties to Protect or Coerce, in: J. Roberts/L. Zedner (eds.), Principled Approaches to Criminal Law and Criminal Justice: Essays in Honour of
} 
to certain outlooks - in spite of the well-established orientation which forbids additive interventions in the field of criminal law - may determine the arousal of Constitutional legitimacy questions in malam partem related to possible National provisions resulting to be "inadequate and defective". 30

The final assessment is therefore inevitably uncertain as well as provisory, and destined to a continuous follow up as the Italian Court - after having entrenched the ECHR within the Constitutional hierarchy of sources of law - shall still be called upon to intervene, articulate and calibrate the process of integration with the European system of protection of human rights.

Professor Andrew Ashworth, 2012; A. Campbell, Positive Obligations under the ECHR: Deprivation of Liberty by Private Actors, in Edinburgh Law Review, 2006, p. 399 et seq.; see also F. Bestagno, Diritti umani e impunità. Obblighi positivi degli Stati in materia penale, 2003, passim.

${ }^{30}$ On this topic F. Viganò, L'arbitrio del non punire. Sugli obblighi di tutela penale dei diritti fondamentali, in: Scritti in onore di M. Romano, vol. IV, 2011, p. 2645 et seq.; E. Nicosia, Convenzione europea dei diritti dell'uomo e diritto penale, 2006, 255 et seq.; C. Paonessa, Gli obblighi di tutela penale, 2009, 167 et seq.; for critical remarks, $V$. Manes, Introduzione. La lunga marcia della Convenzione europea ed i "nuovi" vincoli per l'ordinamento (e per il giudice) penale interno, in: $V$. Manes- $V$. Zagrebelsky (eds.), La Convenzione europea dei diritti dell'uomo nell'ordinamento penale italiano, 2011, 52 et seq.; see further V. Valentini, Diritto penale intertemporale, 2012, 47. 